\title{
Spanish Architecture to Develop New Cities, Miguel Fisac in Abu Dhabi
}

\section{Rubén García Rubio ${ }^{1}$ and Sonsoles Vela Navarro²}

${ }^{1}$ American University in Dubai, Department of Architecture, Dubai, UAE \& Tulane Uniersity, New Orleans, USA

${ }^{2}$ Tulane University, New Orleans, USA

\section{Abstract}

Only 50 years ago, the UAE was composed of a few small villages of fishermen, shopkeepers, and pearl-traders; they lacked paved roads, running water and had only a few telephone lines. Today, it's a fascinating and glimmering young country projected to the future as the result of the sudden discovery of oil in the 60 s and its commercialization.

In the early phases of its urban expansion, foreign architects played an important role due to the lack of tradition in the region of certain professions as designers and some of the most important Spanish architects worked in the region during its blooming in

Corresponding Author: Rubén García Rubio rubiogarciaruben@gmail.com

Received: 15 March 2019 Accepted: 25 May 2019 Published: 20 November 2019

Publishing services provided by Knowledge

(c) Rubén García Rubio and Sonsoles Vela Navarro. This article is distributed under the terms of the

Attribution License, which permits unrestricted use and redistribution provided that the original author and source are credited.

Selection and Peer-review under the responsibility of the Architecture across Boundaries Conference Committee.

\section{G OPEN ACCESS} the 70s and 80s. Although, what could Spain export to the Middle East in those years? This paper will attempt to unfold the contributions of the modern Spanish architecture to the architecture of the Middle East during the blooming of the region. Specifically, it will be focused on the great Spanish architect Miguel Fisac and, in particular, the cultural and technical interchange between two different contexts (as the Spanishand the Emirati), through an innovative twisted skyscraper designed for Abu Dhabi (UAE) in the early 80 s.

Keywords: Spain, Middle East, Abu Dhabi, Miguel Fisac, Export, Modern Architecture, Twisted Tower, Skyscraper.

\section{Introduction}

Only 50 years ago, the UAE was composed of a few small villages of fishermen, shopkeepers, and pearl-traders; they lacked paved roads, running water and had only a few telephone lines. Today, it's a fascinating and glimmering young country projected to the future. How could this transformation happen so fast? This was the result of a complex set of economic, social and urban dynamics. The sudden discovery of oil in the 60 s and its commercialization was a turning point in the history of the Arab country and its capital quickly sprout up from the desert [1].

In the early phases of its urban expansion, foreign architects played an important role because of the lack of tradition in the region of certain professions such as 


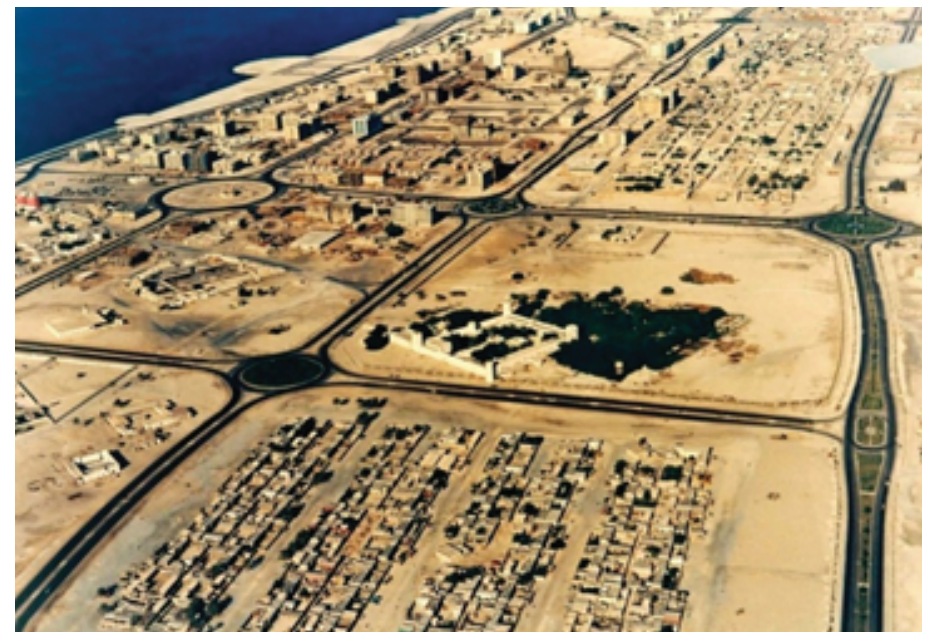

Figure 1: Aerial view of Abu Dhabi in 1974, with the Qasr al-Hosn fort in the center.

designers. Especially, the British architects played a prominent role due to the political and economic ties that they still maintained with different countries of the region. Nevertheless, there were also architects of other nationalities who gave a different perspective to the architecture of the region because of their tangential relation with the place and a more traditional vision of the profession. The competition for the Deira Sea Corniche in Dubai (1974) is an excellent example as the entries of the Pietiläs, Candilis or BBPR showed a strong balance between modern architecture developed in Europe in those years and the traditional architecture of the Middle East [2].

Some of the most important Spanish architects of the 70s and 80s worked abroad and some of them were even involved in the Middle East as Josep Lluis Sert in Iraq, Javier Carvajal, Julio Lafuente and Antonio Vázquez de Castro in Saudi Arabia, or Fernando Higueras and Miguel Fisac in the United Arab Emirates. Nevertheless, it must be remembered that Spain was starting to show recovery signs at the time, because of its Civil War and the aftermath, so its construction industry was still very precarious. Then, what could Spain export to the Middle East in those years?

A deep knowledge of the profession and the building trades is a possible answer. This profound and wide knowledge of both sides of the profession allowed the Spanish architects to build works of high quality in spite of having few resources available and, among all of them, Fisac was one of those who best merged both fields. As proof of that synthesis, he dared to design a bold and innovative twisted skyscraper for a place that was starting its development its building industry, as was still Abu Dhabi (UAE) in the early 80 s.

This paper will attempt to unfold the contributions of the modern Spanish architecture to the architecture of the Middle East during the blooming of the region. Specifically, it 
will be focused on the Spanish architect Miguel Fisac and, in particular, the cultural and technical interchange between two different contexts as the Spanish and the Emirati, through Fisac's twisted skyscraper.

\section{The Architect}

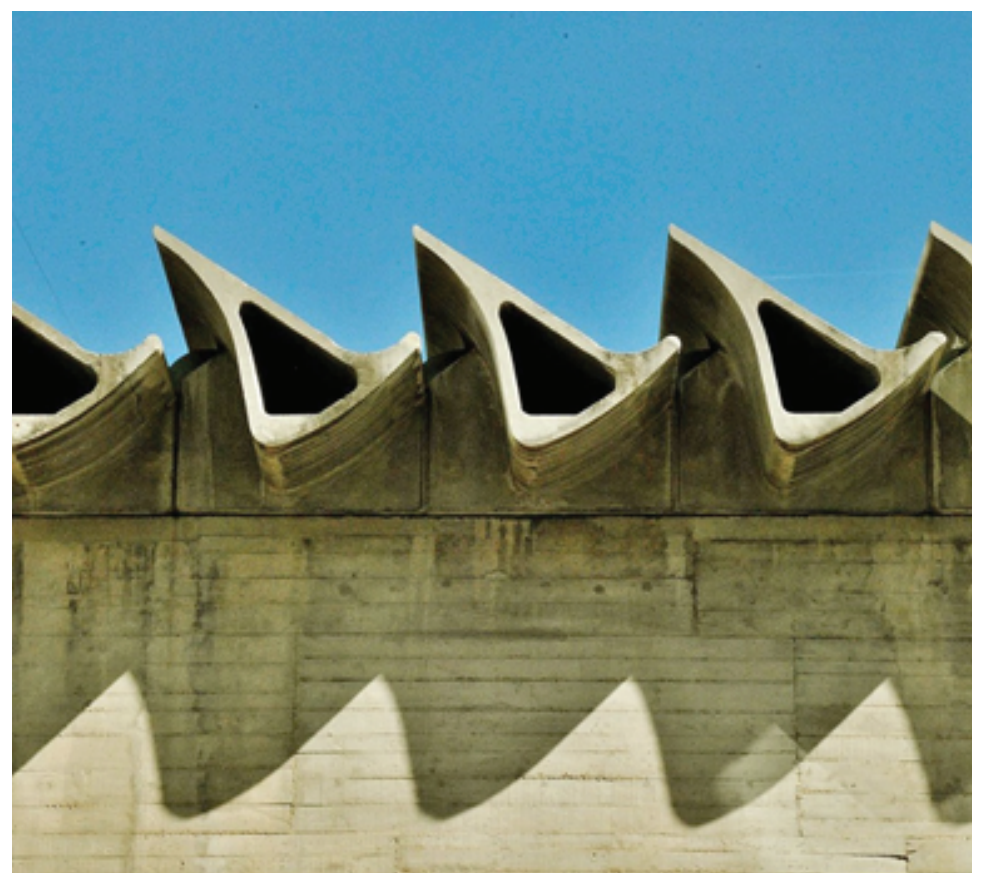

Figure 2: Detail of the "beams-bone" of the Center for Hydrographic Studies in Madrid.

Miguel Fisac (1913-2006) was one of the greatest Spanish architects of the twentieth century. He was among the architects who introduced modern culture to the country and lead the opening and positioning of its architecture abroad. After an initial classical and rationalist phase, Fisac experimented a change of interest towards an organic and empirical architecture, thanks to a trip to Northern Europe and the discovery of another sensibility when tackling the architectural design [3]. These two approaches (rational and organic) [4], in addition to other influences as the Spanish or the Japanese traditional architecture and his passion for learning, shaped Fisac not only as a rigorous and sensitive architect but also as a restless innovator.

Fisac's design can be divided into three different stages. Firstly, there were the organs. Fisac started by creating a specific atmosphere for each need and characteristics of the space. He always followed the same design method answering always the same set of questions, and always in the same order: what, where and how? After then, he always included a "no sé qué" ("I do not know what") which was a subjective approach to the problem and helped him to give a sense of unity to the three answers. Some interesting 
works of this stage were the volumetric articulation of the Teacher Training Center in Madrid (1952-57) or his entry for the Toronto City Hall (Canada, 1957). During this time, the architect also started to experiment with the religious space as in the Reales Dominican Fathers' Catholic School in Valladolid (1952-53), the Church of Nuestra Señora de la Coronación in Vitoria (1957-60) or, abroad, the Church in Escaldes (Andorra, 1951) and the proposal for the competition for the Saint Florian Church in Vienna (Austria, 1956) [5].

Then, there were the bones. Fisac always defended the use of the lintel structure for the roof, as a natural result of the movement of a person within a space [6]. As he did not find an optimal solution to solve lighting, construction and rainwater harvesting at the same time, he invented a new one by using his intuition and creativity. Fisac designed a set of prefabricated hollow concrete beams, which he named as "beamsbone" because of their similar shape with the natural bones. He developed this idea in different buildings as the Center for Hydrographic Studies in Madrid (1960-63), the Made Pharmaceutical Laboratories in Madrid (1960-67) or the Garvey Winery in Jerez de la Frontera (1969-74) and was part of his entry for the Spanish Pavilion at New York World's Fair (1964).

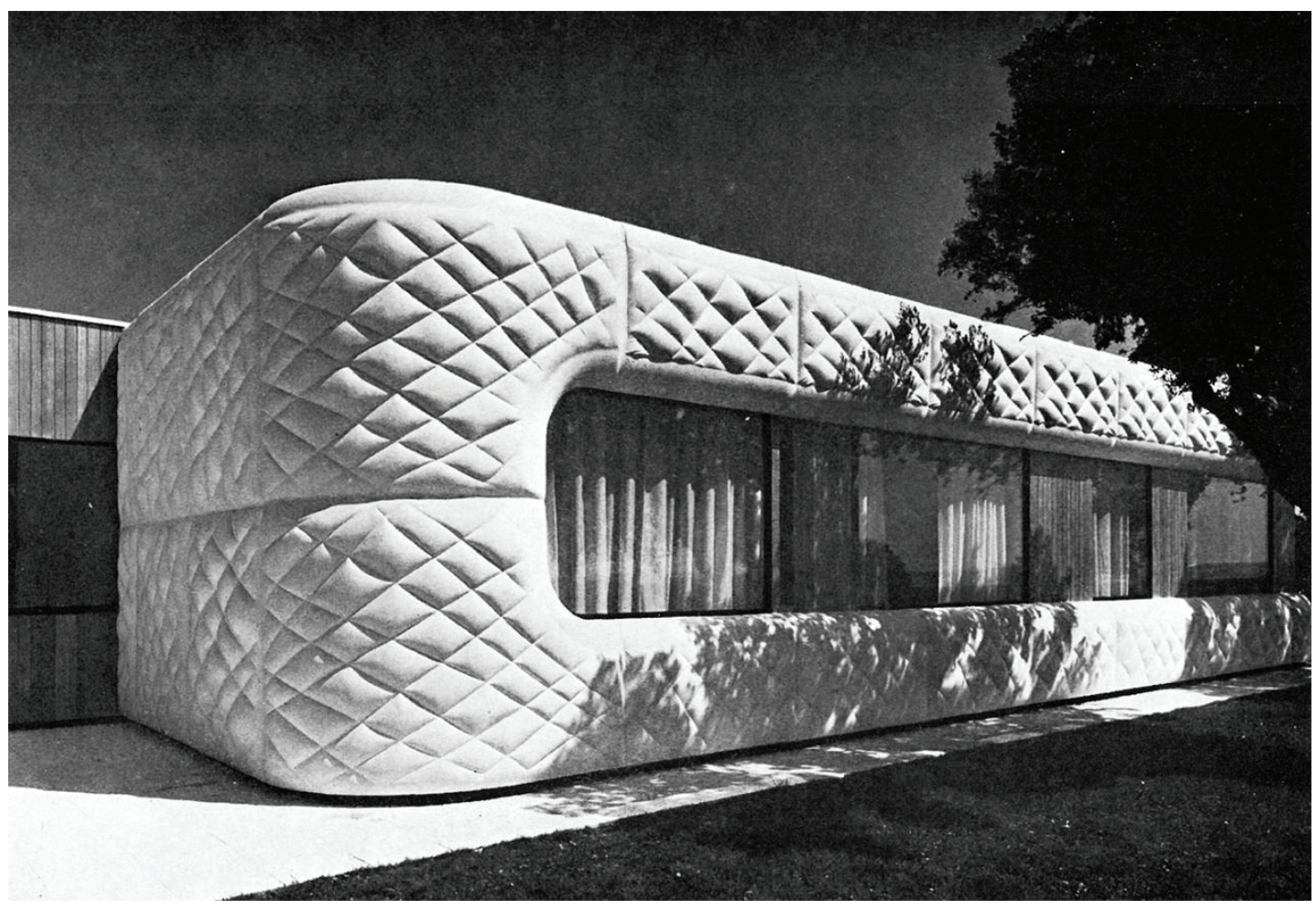

Figure 3: View of the Pascual de Juan House.

Finally, there was the skin. Fisac, following his constructive, empiric and organic approach to the architecture, realized on the original state and the inherent logic of the 
concrete as a liquid element and he invented a flexible formwork (based on the use of metallic wires and plastic sheets). This constructive system allowed him to show a different finishing of this material, which showed a soft and elastic texture in contrast with the hardness and stiffness usually associated with it. The architect experimented with this technique in different buildings with different textures like the Mupag Rehabilitation Center in Madrid (1969-73), Pascual de Juan House in La Moraleja (1973-75) or the Hermanas Hospitalarias Social Center in Ciempozuelos (1985-86).

\section{Fisac and the UAE}

Miguel Fisac started his contact with the United Arab Emirates in 1970. His restless character and a decrease quantity of work in his studio encouraged the architect to establish contacts with the Arab world in general and the Emirati in particular. For more than a decade, Fisac established and reinforced a relation with the country that has not been studied yet as part of his biography [7]. This relationship allowed the architect not only to travel to the region twice but also to work in different designs and activities related to the architecture.

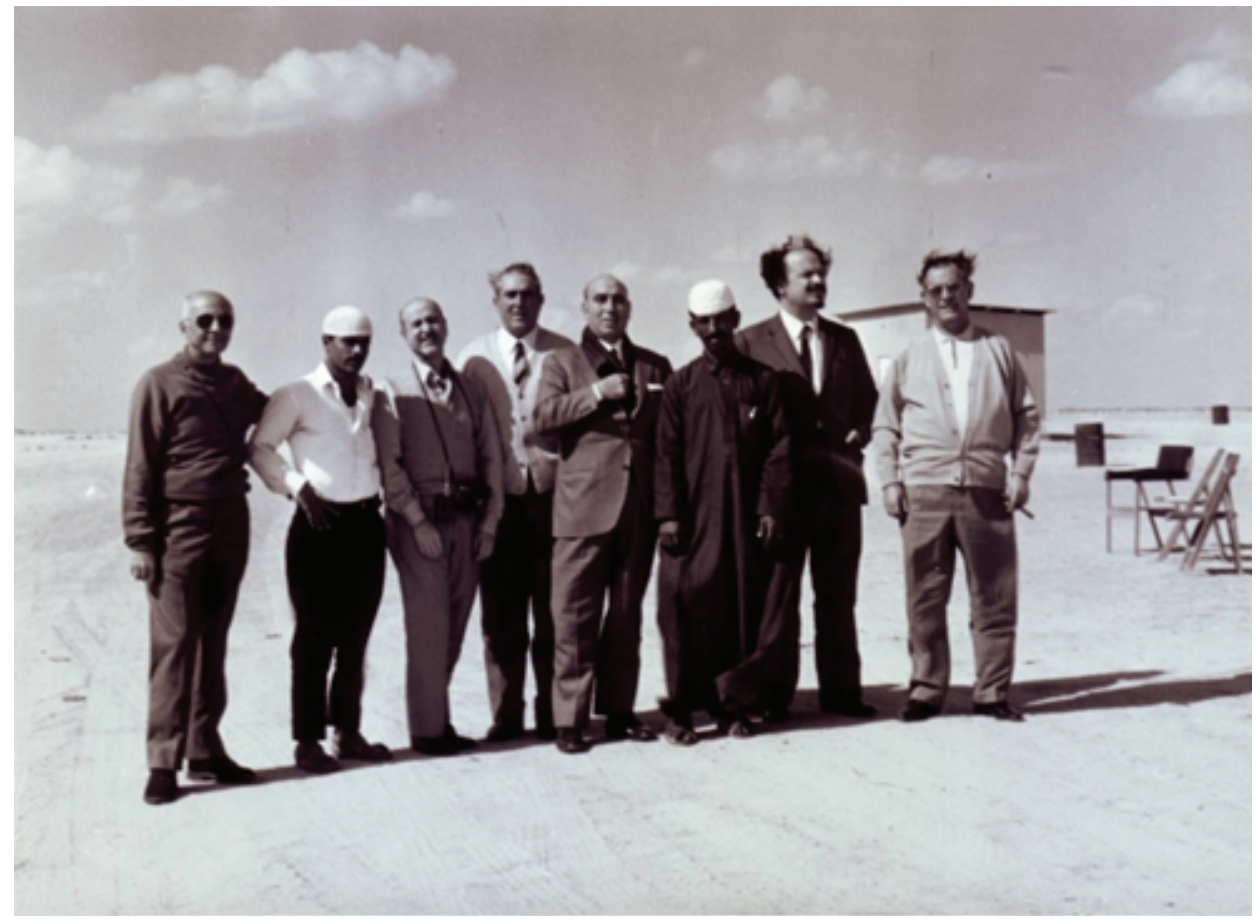

Figure 4: Miguel Fisac (third from the left) during a visit to Similiyat Island in 1981.

His relation with the region started with a trip between January and February 1970, with stops in Abu Dhabi, Dubai, and Bahrain [8]. After this trip, Fisac established some contacts with different figures related to the Arab countries (mostly in Spain). On account 
of these connections, he was invited to participate in some architectural and urban designs by the Sheikh Zayed bin Sultan Al Nahyan [9]. Nevertheless, Fisac's first design for the region was a proposal for a competition for the design of a Hotel in 1976.

After that, Fisac visited again Abu Dhabi as a member of the Jury for the competition to design the masterplan and landscape of the Similiyat Island in Abu Dhabi in 1981 [10]. After this trip, the bonds between Fisac and Abu Dhabi increased as he designed three different proposals for the city in the following months: a Conference Hall, a Convention, and Exhibition Center and a mixed-used Tower.

\subsection{Fisac's proposal for a Convention and Exhibition Center in Abu Dhabi}

Among all the proposals designed by Fisac for Abu Dhabi, the Convention and Exhibition Center is the most interesting one.

The entire complex is organized along a central axis, which is crown by a sculptural tower in its center. This tower has two exhibitions buildings on both sides, with a latticework facade based on Islamic geometric patterns, and a big building in the back, with a vertical facade composition as the tower. These three buildings are connected by a colonnade portico and, along with the tower, define a courtyard with a traditional Islamic garden in the center.

The complex has also a small administrative building in one side, a building for big events at the back (which interprets the traditional tents), and a set of gardens in the front of the plot that follow the Islamic tradition of mixing water and vegetation under geometric patterns.

Nonetheless, the tower is the most distinguished part of the complex, not only for its position and dimension but also because of the boldness of its shape, as Fisac proposes a twisted tower. The 30-story tower has a square floor plan that progressively rotates its floor plates as it gains height. In this case, the top offset is 45 degrees from the base, so each floor rotates 1.5 degrees in relation to the lower one around a vertical axis. Thus, the exterior surface has not an orthogonal shape but a helical one.

Despite the audacity and dynamism of the external shape, the complexity of the structure of the building lies mainly in being a 30-story tower. The reason is that the structural columns are placed within the octagon that results from the rotation of the floor slabs so only a small triangular part of them is cantilevered. Therefore, the most important issue is the solution of the ruled surface of its façade. 


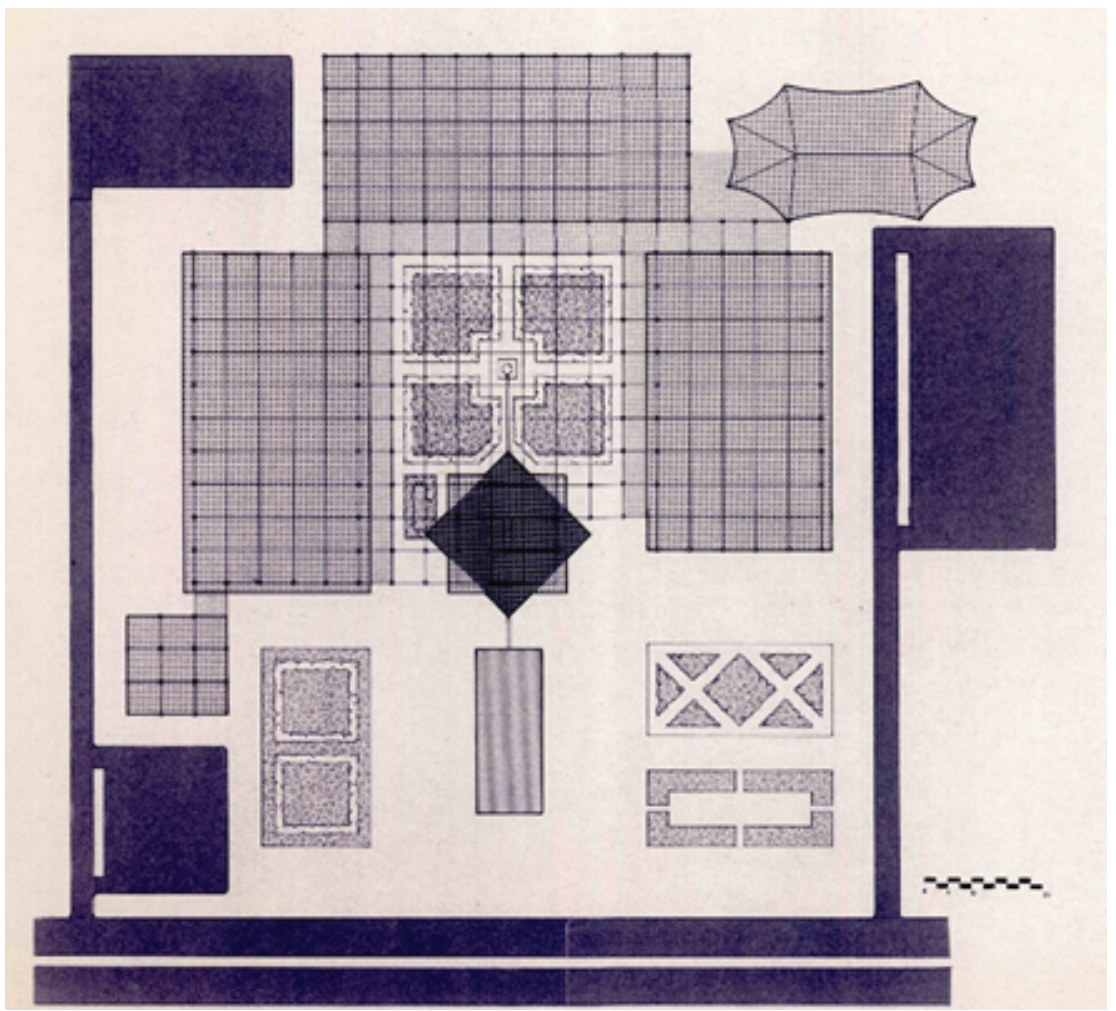

Figure 5: General plan of the Convention and Exhibition Center Complex.

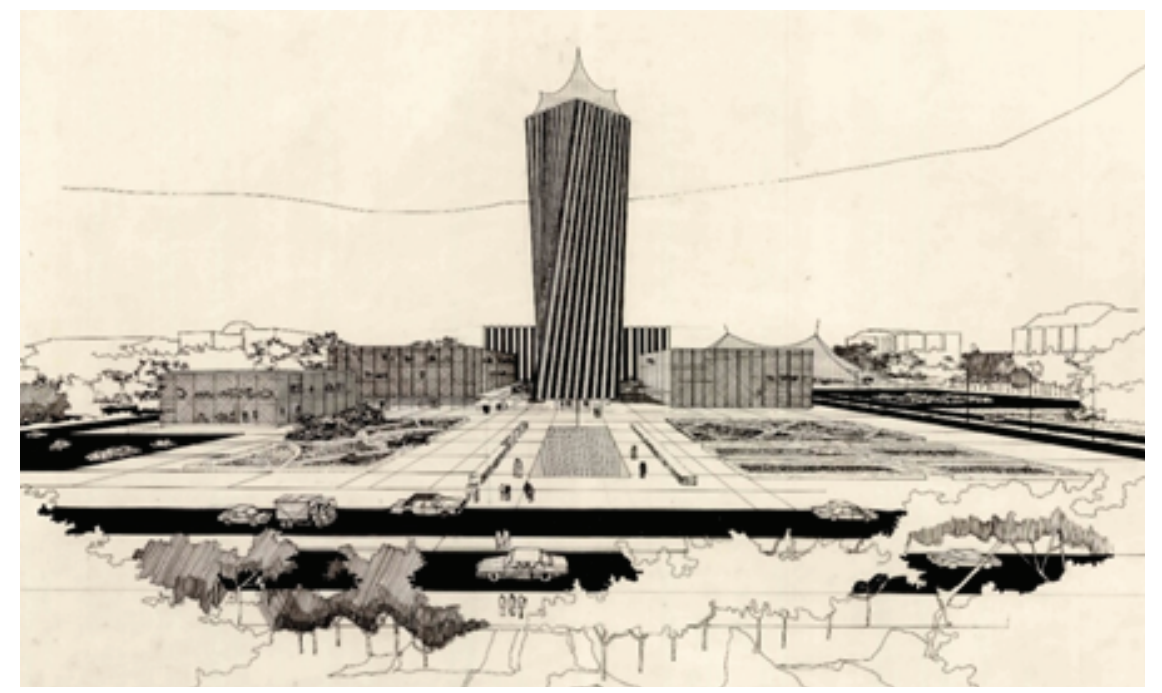

Figure 6: General view of the Convention and Exhibition Center Complex.

In addition, the tower is crowned by a "structural and artistic solution which consists of a big camp tent made of transparent shells hanging from steel cables." [11] All of these characteristics would have given a "great beauty" to the tower, according to the own architect [12]. 


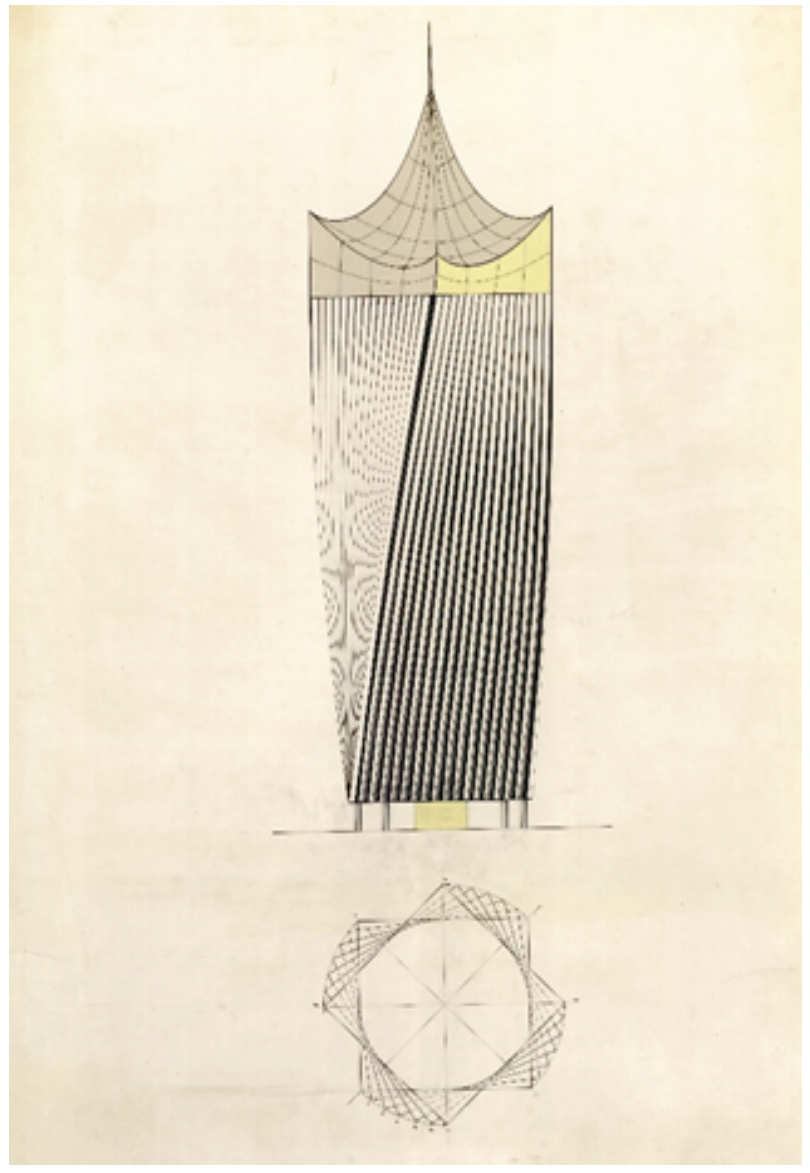

Figure 7: Plan and Façade of the Twisted Tower.

\subsection{Exporting Sensibility and Technique}

Fisac had already worked with a similar shape some years before when he designed "La Pagoda", the tower of the Jorba Laboratories $(1965-67,1999)$ on the outskirts of Madrid. In that case, the tower was composed of five square floors rotated 45 degrees between each other. Then those floors were connected by two concrete hyperbolic paraboloid parapets (upper and lower). The architect also proposed in Spain a basic vertical structure composed of eight pillars placed within the projection of the rotating floors [13]. Similarly, he also designed a particular element at the top of the building [14]. All together composed an advertisement-tower (following the client's desire) with a high sculptural and technical component, which became quickly a symbol of the Spanish capital.

Sensibility and technique characterized "La Pagoda" and Fisac wanted to bring both to Abu Dhabi. On the one hand, the sensibility to shape the architectural form according to its context, function, and symbolism. Fisac knew that a simple geometric manipulation could shape elements with a high plastic value. The architect took the most interesting 
part of "La Pagoda," the hyperbolic paraboloid parapet, and developed it for an entire building, so the result was a twisted tower. Hence, Fisac could export to Abu Dhabi the value of the form that he had learned in Spain, his "I do not know what," and especially for a city and a region eager for modern icons to establish his new position in the world.

That sensibility also encouraged Fisac to understand the place and to design consequently. That is why the overall layout was composed following geometrical patterns, having the courtyard as the main concept and using vegetation and water to characterize the external spaces. Beyond those main ideas, the architect also included to his designs other small local gestures as the extensive use of latticework or the proposal of a textile structure.

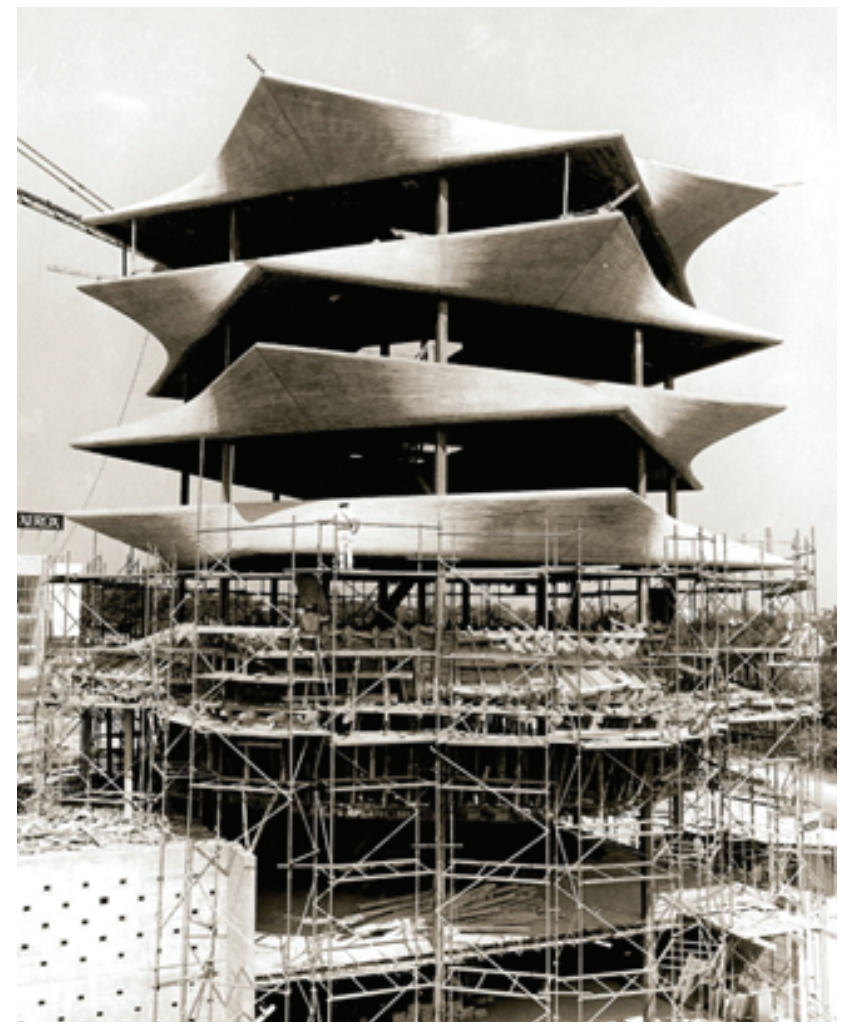

Figure 8: "La Pagoda", the tower of the Jorba Laboratories, during its construction.

On the other hand, the knowledge and cleverness to simplify complex concepts or processes into simple ones. For example, when simplifying the structure of the tower by placing the columns in the interior part or solving the complex geometry by craft means and unskilled labor. As mentioned before, both the Spanish and the Emirati construction industry were very precarious in that time (the former because of its Civil War and the aftermath and the later due to its recent new reality after the discovery of the oil) and there was a big gap between their concrete industry and the leading countries in the world in this field at that time. Therefore, Fisac's tectonic approach and awareness of 
an easy-to-use material as concrete, and his ability to build prefabricated elements in a handcrafted manner (all of them showed in his Spanish work), would have been suitable skills to work in the Arab Country those years. [15]

In fact, this work would have allowed Fisac to start a new line of research in both bones and skin. This project would have fostered him to research about vertical structures (not only horizontal bones as he had done until that moment) and to develop the solution for a ruled surface façade that he started in Jorba but this time in a bigger and more complicated scale.

\section{Conclusion}

Miguel Fisac's tower would have been a turning point for Abu Dhabi and the region. Firstly, it would have fostered the advance of the construction industry of the country with his knowledge transfer from Spain. Especially, it would have helped to develop the learning of the concrete and the systems of prefabrication with this material.

Secondly, it would have radically changed the skyline of the country and its capital, as happened in Madrid with "La Pagoda", because this was still a flat and low skyline at the time. Most of the buildings of the city were single houses as there were only a few residential buildings, and the maximum height was between 7-8 floors. The only exception was the 39-story World Trade Center (1979) designed by John Harris on the outskirts of Dubai. Hence, Fisac's proposals could have encouraged the race to the sky also in the capital and maybe the "skyscraper city" could have been a different one nowadays.

Finally, Fisac's twisted tower would have placed both the UAE and its capital and the Spanish architecture in an important international position in architectural and technological terms. Currently, this specific typology of skyscrapers with twisted structures are becoming more common but, at that moment, this type of structure was still a longing, especially because of the lack of technology to achieve the complexity of this typology [16]. Thus, this building would have attracted much international attention. Unfortunately, Fisac had in mind an update of the "the Alhambra of Granada" while the Emirati client "wanted the White House of Washington" [17], so this interesting idea could not change the skyline of Abu Dhabi. 


\section{Acknowledgment}

The authors would like to thank Miguel Fisac Foundation and its President Diego Peris Sánchez for their contribution and support to the research.

\section{Conflict of Interest}

The authors have no conflict of interest to declare.

\section{References}

[1] The following papers explain in depth the evolution of the main cities of the UAE from the 50s until nowadays: García, R., Aglieri, T., Urban Impulses. Notes to Understand the Present and the Future of Dubai, Zarch. Journal of interdisciplinary studies in Architecture and Urbanism, n. 8, pp.78-88; García, R., Building Dubai, the legacy of John Harris, ANANKE. United Arab Emirates: Urban Landscape and Modern Heritage, n 86, pp. 114-19; Sosa, M., Ahmad, L., Emirati Memories, documenting architectural modern heritage, in the UAE, ANANKE. United Arab Emirates: Urban Landscape and Modern Heritage, $\mathrm{n}^{\circ}$ 86, pp. 134-38; and, Roldan, J., Sharjah: Bedouin, Trucial and Arts State, ANANKE. United Arab Emirates: Urban Landscape and Modern Heritage, n 86, pp. 129-34.

[2] Aglieri, T., Dubai, 1974. Reima and Raili Pietilä's project for the Deira Sea Corniche Competition, ANANKE. United Arab Emirates: Urban Landscape and Modern Heritage, n 86, pp. 119-23.

[3] Delgado, E., Aparicio, J., (2017). Recogiendo conchas en la arena. Las libretas de viaje de Miguel Fisac. $P+C$ : Proyecto y Ciudad: Revista de temas de arquitectura, $n$ 8, pp. 7-22.

[4] Arques, F., (2010). "Una biografía arquitectónica”: in Fisac, M., Espuelas, M., Arques, F., et al. (2010). Miguel Fisac. Premio Nacional de Arquitectura 2002. Madrid: Editorial Lampreave, p. 34.

[5] Fisac worked very little outside Spain, and almost all those designs are listed in this text and almost all of them were done for the UAE.

[6] Ibid. p. 37.

[7] Only a few texts study Fisac's relation with the UAE and all of them treat this topic generically. Delgado, E., Aparicio, J., (2017). Recogiendo conchas en la arena. Las libretas de viaje de Miguel Fisac. P+C: Proyecto y Ciudad: Revista de temas de 
arquitectura, n 8, pp. 7-22; Peinado, Z., (2014). "Los apuntes de Miguel Fisac en sus viajes": in Melián, A., (Ed.), El dibujo de viaje de los arquitectos. Las Palmas: Universidad de Las Palmas, pp. 597-603; Fisac, M., Espuelas, M., Arques, F., et al. (2010). Miguel Fisac. Premio Nacional de Arquitectura 2002. Madrid: Editorial Lampreave, pp. 380-81: Arques, F., (1996). Miguel Fisac. Madrid: Editorial Pronaos, p. 20.

[8] There is a small travel book in the Miguel Fisac Foundation regarding this trip. Miguel Fisac Foundation: AFF342.

[9] The Foundation also preserved some letters regarding this invitation. AFF342.

[10] There is another small travel book and some documents regarding this trip and the competition in the Foundation. AFF342.

[11] In reality, this is the description of the higher part of another tower designed for Abu Dhabi by Fisac a few months later, which that uses the same solution. This text is also preserved at the Foundation. AFF342.

[12] There is a short memory and a few drawings where the Fisac described the design of the complex and, specifically, the tower. AFF342.

[13] Peris, D., (2015). Miguel Fisac: Arquitecturas para la investigación y la industria. Madrid: Bubok, p. 98

[14] Fisac also proposed another particular element to crown the entry courtyard of his design for the Embassy of Spain in Canberra (Australia, 1987), which was his last project abroad. Miguel Fisac. Premio Nacional de Arquitectura 2002. Madrid: Editorial Lampreave, pp. 390-91.

[15] As a matter of fact, concrete has become one of the most popular materials in the country in the last decades.

[16] The Council on Tall Buildings and Urban Habitat has registered 15 built twisted towers, and another 13 under construction, in a recent report. http://www.ctbuh.org/ redirect.php?tab_id=7295.

[17] Diego Peris pointed out this quote in conversation with the author. Sevilla Lozano, J., (2014). Miguel Fisac. ¿Arquitecto de Dios o del "Diablo”? Madrid: Editorial Nueva Utopía, p. 299. 